Article

\title{
How to Retain Global Talent? Economic and Social Integration of Chinese Students in Finland
}

\author{
Hanwei Li \\ Manchester China Institute, School of Social Sciences, University of Manchester, Manchester M139PL, UK; \\ hanwei.li-2@manchester.ac.uk or stflihanwei@gmail.com; Tel.: +358-(0)-45171-5538
}

Received: 27 February 2020; Accepted: 5 May 2020; Published: 19 May 2020

\begin{abstract}
Global talent is the key resource for today's knowledge-based society and sustainable economic development, and an increasing number of countries are aiming to not only train but also to retain international students as a potential supply of highly skilled labor in innovative fields. This article explores ways to retain international students as global talent through an empirical study on mainland Chinese students' integration into Finland as an example. Based on data obtained through semi-structured interviews with 30 Chinese students, this research identified a number of individual and societal factors that contribute to their difficulties with economic and social integration. The findings demonstrate the complexities of the language barrier faced by Chinese students in non-Anglophone country contexts, and the important interplay between students' social and economic integration. The host environment (nation-states and organizations) also plays a vital role in creating a more open and multicultural environment to enhance the capacity of such young people to integrate and innovate. This paper concludes with a number of proposals for individuals, organizations (including higher education institutions (HEIs), and nation-states to consider for innovating their policies and measures to better integrate global talent.
\end{abstract}

Keywords: global talent; social integration; economic integration; innovation ecosystem; Chinese student; Finland

\section{Introduction}

Highly skilled workers increasingly play a central and indispensable role in today's knowledge economy. Through scientific discoveries and breakthrough innovations, talented individuals not only push through new frontiers of knowledge, but also expedite economic development. Developed economies (such as Finland) around the world are increasingly competing for highly skilled migrants, who potentially have better labor market prospects and satisfy the need to achieve global sustainable development [1-3]. Highly skilled migrants boost innovation, which is the key path to sustainable long-term growth and breakthrough performance. To satisfy the needs of environmentally sustainable economic development and the knowledge economy, more and more countries realize the importance of attracting and integrating global talent through an environment supportive of research and innovation [4]. However, the number of potential immigrants with high economic potential who can also easily integrate into the host labor market is limited, and more and more global talent are becoming increasingly selective about career potential and social welfare in the host country [5]. Thus, immigrant receiving countries rely on retaining international students as a source of highly skilled workforce, since the students have earned their credentials in the host society and are expected to be better integrated due to their cultural and linguistic competences. However, many studies have shown that international students face serious challenges to their integration (e.g., [6-8]), which implies urgent need for integration policies to complement immigration policies. 
Global talent (or international talent) is generally defined as people with professional knowledge and global skills with potential to generate great values [9]. Global talent can be an international student, a researcher, an accompanying spouse, a work migrant, an asylum seeker, or a returnee [1]. Global talent usually refers to those who hold higher tertiary education degrees, but it can also refer to highly skilled individuals who have high expertise in a certain field. For organizations, global talent management generally includes different organizational activities for attracting, selecting, developing, and retaining the best employees in the most strategic roles on a global scale [10]. In this research, global talent specifically refers to international students pursuing degrees or young researchers conducting research in countries other than their countries of origin, since they are potential innovators or entrepreneurs who are critical to contribute to breakthroughs in technology, knowledge, and modes of new production [11].

The integration of international students as global talent is important for a number of reasons for the knowledge-based society and sustainable economic development. First, global talent are key actors in building the transnational innovation ecosystem. The transnational innovation ecosystem is generally defined as the transnational integration process of two or more innovation ecosystems [12,13]. It builds on the concept of innovation ecosystem, which is characterized by co-evolution of different collaborative actors that develop interdependency over time for sustainable development $[4,14,15]$. Since international students have the socio-cultural and business-related knowledge and network with both home and host countries, they can be an important link in fostering trust between various actors in the transnational innovation ecosystem. In transnational contexts, more distance between the collaborators and more sophisticated institutional structure requires global talent with an understanding of two or more cultures to build trust for successful research and innovative cooperation.

Second, skilled persons including students and researchers have been incorporated into the "sustainable development" strategies of institutions, regions, and nation-states [16]. Due to the increasing link between the knowledge-based society and a growing public awareness of the need for environmentally sustainable development [4], global talent, including international students, become a valuable resource to be tapped. Promotion of the mobility of students and highly skilled professionals is outlined in the Europe 2020 strategy for a smart, sustainable, and inclusive growth in a global economy [17]. As Chinese students are one of the largest groups of international students around the world, many higher education institutions in Europe are relying on attracting them for their own fiscal sustainability. The report on EU-China student and academic staff mobility clearly states that many European universities face the challenge in "ensuring sustainable market growth in a mature market." Students especially are increasingly seeking globally, for education that ensures a good value of return for their investment, in terms of money, quality, and institutional reputation [18]. Meanwhile, the mobility of Chinese students presents both an opportunity for EU countries to retain as high skilled labor, and a sustainability challenge for China due to the problem of brain drain. To maintain and nurture the sustainable knowledge network, both EU and China have been designing competitive and sustainable knowledge network and international partnership for mobile academics, institutions, and broader societies [16].

Third, a substantial body of literature has shown that many countries have enjoyed net innovation and productivity gains as a result of talent inflows, with the United States being the most studied and prominent case [19]. Highly skilled immigrants boost innovation and productivity through the increased number of individuals pursuing innovative work, while transnational innovative collaboration boosts the revolution of the global innovation ecosystem. As more and more developed societies around the world are seeking high-potential global talent to boost their knowledge-based economies, international student mobility and international experience are promoted as key to knowledge transfer and sustainable development. [20]. Thus, international students who are equipped with international experience and an internationalized curriculum are ideal candidates for many countries to compete for to support their high skilled labor market demand. 
Fourth, international graduates have better potential of economic and social integration than highly skilled workers recruited directly from abroad. Besides saving on the relocation costs, the benefits of recruiting international graduates also include: Proficiency in the local languages; capability to build transnational professional networks, and understanding of the socio-cultural and business-related aspects of home and host countries [19]. Previous research suggests that students might have less incentive to return to their countries of origin, because they spend important life phases, for building friendships and relations or starting families, in the host country. Those relations will develop into personal attachments in the host country and can result in fewer incentives to return than highly skilled workers who built their social network before moving to the host country [7].

Finland only joined the global race for highly skilled professionals in recent decades. With its economic development spurred by technological development, Finland has changed from a country of emigration to one of immigration, and has sustained its focus on economic development based on technological advancement and sustainable development. Due to its increasing demand for highly skilled workers and the projected aging population leading to a diminution of the working age population, Finnish immigration has continued to open up its policy to recruit and encourage international students to stay to find work or start businesses after graduation. Initially, international students were only allowed to stay for six months to seek employment after finishing their tertiary education in Finland. However, ever since 2015, such students are allowed to stay to find work for up to one year following the completion of their studies [21]. A recent report by the Finnish government suggested good practices of government models to incorporate global talent into the Finnish innovation economy, and proposed a long-term vision that "Finland has attractive, inclusive and sustainable innovation ecosystems that thrive from diversity" [1]. To achieve this goal, it suggests having "both public and private stakeholders on board and financially committed," to develop sustainable funding and business models and incentives for demonstrating impact (ibid.).

Despite the explicit policy and agenda to attract and integrate international students as global talent in the labor market, studies on whether and how international students integrate into the host society, if planning to stay in the country remain scarce. Many of the studies have focused on the drivers of international students' mobility and the experience of studying abroad (e.g., [22]). In general, less attention has been paid to the integration outcomes of the international students beyond academic contexts, especially their study-to-work transition [23]. Nevertheless, a small number of studies can be found showing that economic and social integration of international graduates aiming to remain in the host society can be difficult to achieve (e.g., [24,25]). However, these studies mainly focus on international students' experiences in Anglophone countries, while non-Anglophone country contexts deserve more scholarly attention since the local language can pose additional challenges to international students' integration. Meanwhile, since countries like Finland are aiming to retain international students as highly skilled workers, it is also crucial to understand how the students integrate into the societal contexts if they plan to remain after graduation. This research aims to fill in the gap by exploring the following questions:

RQ1: How do Chinese students integrate economically and socially into the host society if planning to stay in the country?

RQ2: What are the individual and societal factors that affect the economic and social integration of Chinese students?

Given the large and growing percentage of overseas Chinese students and scholars who study abroad, their integration into the local society has become an increasingly pressing issue. A number of studies in the context of other countries have demonstrated that good integration can be difficult to achieve (e.g., [26-30]).

\section{Literature Review and Analytical Framework}

Although there is a lot of literature dealing with student integration, these studies mainly look at the issues from a narrow perspective. There is an urgent need to generate a comprehensive understanding 
of the term and phenomenon through synthesizing the literature. While the term 'integration' is frequently used in different fields of literature, its meaning can be quite different in different contexts. Building on the conceptualization of integration provided by International Organization for Migration (IOM) [31], I define it as follows: A bidirectional process of mutual adaptation between the host society and migrants (in this case international students) themselves, both as individuals and as groups. As this definition suggests, students' integration cannot be achieved purely by individual or group effort, but rather requires a combined effort by multiple stakeholders, including students, educators, university administrators, employers, and policymakers. From the host society perspective, it also entails a more receptive and welcoming environment that incorporates newcomers to become part of the enlarged membership in the host community, while allowing newcomers to maintain their ethnic and cultural heritage [32].

As theory is central to enhance our understanding of the world, the current research finds the most appropriate theoretical perspective for analyzing the current research topic is the structure and agency approach. Structure is often referred to as objective social institutions that affect the way people act and live, while agency is usually referred to as human choice, action, and deliberation. This brings in the paper by Tholen [33], in which he discusses the interplay between agency and structure through empirical investigation of graduate employability. Tholen (2015) proposes that graduate employability is not solely individual phenomenon, but structured by inequalities and opportunities within the structural context, and influenced by the labor-market hierarchy. Meanwhile, individuals' identities also decide their competition strategy for jobs. Some studies point out that an individual's labor market decision is not solely economic calculations, but choices are also based on their ethnicity, class, gender, life history, and other backgrounds (e.g., e.g., [34,35]). Thus, understanding of international students' integration in the host country requires a contextual analysis of both, since individuals' agency is embedded in different contexts where social relations are constituted and negotiated. However, this does not exclude individuals who have the capability to rebel against existing social structures, especially in circumstances where certain groups dominate other groups by utilizing their position within society, or forms of capital or scarce resources [33].

Although the main aim of the current research is to analyze the students' integration into host society as global talent, which centralize the importance of economic integration, social integration also constitutes an integral part that influences and shapes the integration trajectory. Previous research [26] highlights the importance of understanding the interplay between different domains of integration, that economic and social integration are influential and endogenous for each other.

In sum, adopting the theoretical approach of agency and structure, the current research mainly examines students' economic integration through two domains, namely individual and societal factors. In addition, the relations individuals have also influence how they interpret, react, negotiate, or resist existing societal structures. Therefore, social integration is incorporated as another domain to examine its interplay with economic integration, and to offer a more comprehensive understanding of student integration.

\subsection{Economic Integration}

The term economic integration is defined in general as the migrants' process of joining in economic participation or finding and retaining job opportunities in the host country's labor market [36,37]. Within the field of higher education, it is often referred to as 'employability' in some literature, which Shumilova and Cai [19] define as a graduate's ability to find work, which is influenced by employers' beliefs and other contextual factors. It also involves a 'psycho-social construct' that combines with other individual characteristics to ensure individuals maintain work in uncertain economic environments [38]. 


\subsubsection{Individual Factors}

Past research shows that although international students are prepared to function as global talent with intercultural savvy and job related skills [39], and who may potentially be more employable than local graduates [40,41], the reality is often not as expected. International graduates are often more vulnerable [42] and face more challenges in the labor market than do local graduates [43]. From an individual's perspective, when international students are seeking employment in the host country, especially where the local society is more homogenous, ethnicity can be an important factor that causes some foreign graduates to face discrimination when applying for a job [44,45]. Access to professional networks also plays an important role since foreign job seekers may well lack professional ties to help them find work and local employers may have reservations about hiring foreigners. Those who are recommended by a previous employer or people that they know may have a better chance of being hired [46]. Studies conducted on international graduates' employment $[43,47,48]$ identified a number of challenges they face, including restrictive immigration policy, lack of professional networks, family reunion issues, language barriers, racial discrimination, etc.

\subsubsection{Societal Factors}

International students' economic integration does not merely depend on individual competencies and agencies, but also on structural contexts, namely societal factors, such as the prevailing labor market situation, employers' perceptions and needs, relevant government policies in the country, etc. [49-51]. From a government and employer perspective, there seems to be a paradox in the recruitment of foreigners. On the one hand, the national agenda in many countries has emphasized the importance of retaining foreign talent. However, the legislation in the EU and at the local level still protects the rights of local and EU citizens in such a way that employers should prioritize hiring their own citizens, then EU citizens, and finally non-EU/EEA (European Economic Area) citizens [1,52]. Foreign applicants may face discrimination from potential employers. For instance, the Eurobarometer survey shows that $52 \%$ of Finnish employers mentioned that when choosing between two candidates with comparable qualifications, one's ethnic origin and skin color could put a job applicant in a disadvantaged position [53]. Although nation-states and organizations (including universities) are increasingly aware of the importance of retaining international graduates and supporting their economic integration, they still see the primary responsibility as resting with the individual [49].

\subsection{Social Integration}

Building on the conceptualization provided by Ware et al. [54] and Spencer-Oatey [24], social integration is defined as the process through which individuals develop their interpersonal networks and involvement in communities. Social integration is an ongoing process involving not only social interaction between individuals but also involvement in groups and communities. It can refer to students' social activities in academic settings, such as meeting formally or non-formally for academic work, or in non-academic settings, such as involvement in social activities, building friendships with each other.

Studies in higher education have also pointed out that social integration helps with better academic integration $[28,55]$ and student well-being [56,57]. Three types of networks were identified by Bochner et al. [58]: Co-national networks with people from the same ethnicity or countries of origin; host-national networks with people from host society; and multinational networks with other international sojourners. Past research has repeatedly documented that stress, culture shock, loneliness, and homesickness can be a problem particularly for international students (e.g., [57]. A number of studies have reported that networks and friendships between international and domestic students contribute to lowering stress, alleviating loneliness, enhancing psychological well-being overall [59]. However, local and international students have difficulties integrating well with each other (e.g., $[26,60]$. A number of obstacles have been identified, including cultural differences, language and 
communication difficulties, different learning styles and/or lifestyles, lack of common social groups, or lack of common interests [24]. The co-national networks can be important for enhancing students' social integration, since having peers with similar linguistic and cultural backgrounds also helps alleviate the stress of integrating to new environment, and provides essential psychological and social support [61]. However, exclusive engagement with co-nationals can also inhibit students from forming networks with the host-nationals, acquire the cross-cultural communication competency, acquiring or improving linguistic skills [61].

A review of existing literature reveals four gaps: First, existing research on students' integration mainly examines their integration in academic contexts, while their integration in the broader societal context as migrants is less studied. Meanwhile, research on economic integration of foreigners in the countries of immigration generally focus on types of migrants such as refugees, family migrants, or economic migrants; less attention is directed on international students' integration into the host society, who came to the host society first as a student and have different integration trajectories than other types of migrants. Second, the research on students' economic integration (or employability) often addresses the students' own characteristics and competency, as well as institutions' (such as higher education institutions) assistance with students' transition to the labor market; there is less discussion about the societal factors that can facilitate or hinder foreigners to compete in the labor market. Third, less research has addressed international students' economic integration and social integration collectively to explore how they influence, enhance, or inhibit each other. Finally, less research so far has addressed international students' integration in non-Anglophone EU countries, if they plan to stay after graduation. Thus, the current research aims to fill in these gaps through the empirical study of Chinese students' integration in Finland, and shed light on how non-Anglophone countries like Finland can address existing issues to retain more global talent to build sustainable innovation economy.

\section{Methods and Methodology}

A qualitative research design is used in this research, in which data were analyzed through thematic analysis, which allows the researcher to focus on research questions when analyzing the data. This research draws on data collected through semi-structured interviews with 30 mainland Chinese tertiary students who pursued degrees in Finnish higher education institutions (HEIs) from 2015 to 2016. An interview is where 'knowledge is constructed in the interaction between the interviewer and the interviewee' [62]. This study uses interview as a research method because it allows the researcher to guide the research participant into the topic and obtain more in-depth information through interactive conversation. As a qualitative study, the purpose of this research was to achieve a nuanced understanding of the Chinese students' economic and social integration experiences and the meanings they attached to those experiences. Choosing interview as a method enabled the participants to talk freely, consider the question deeply, and offer opportunities to follow up on issues deemed as important or emerging from the interactive conversation [63].

The current research used two methods to recruit interviewees: First, the researcher contacted international offices of HEIs across Finland to send out research invitations to existing mainland Chinese students. Second, the researcher sent out invitations through online social platforms such as Wechat, Facebook, Weibo. Later, snowball sampling was also used to encourage research participants to recruit potential research participants through their friends. Permission to collect data from the research participants was approved by the Ethics Committee of the Tampere Region, Finland. Both Finnish universities and universities of applied sciences are included in this research, and interviewees are located in most of the major cities in Finland, such as Tampere, Helsinki, Turku, Oulu, etc.

Research respondents in this study include 18 female and 12 male, with various backgrounds in terms of major of study, age, pre-migratory study and work experience, duration of residence in Finland. Such variety of study, pre-migratory experience, and duration of residence allows the 
researcher to explore the research respondents' integration aspiration, experience, and future goals in different phases of integration trajectory.

The interviews were conducted in Mandarin Chinese by the author, and generally lasted from one to three hours. The common cultural and linguistic background allows the interviewees and interviewer to create a relaxed atmosphere and engage in open conversations [64]. All interviews were audio recorded (with written consent from the participants), and later transcribed and anonymized for qualitative data analysis.

This research adopts a thematic analysis to identify patterns in the interview transcripts [65]. The thematic analysis followed four typical stages:

First, the transcript is read and familiarized, main themes and thematic codes are generated both deductively from the literature review and inductively from the data to capture the essence of the interviewees' experiences.

Second, for each theme unique to a group, a statement is written. This statement is condensed to a label, and the label becomes a code. Initial codes were generated and used for coding the data, while open coding is performed simultaneously. Either one sentence or one paragraph is the unit of analysis for coding, and multiple codes can be used for one sentence or paragraph. The coding process involved constant review and rewriting the codes for applicability to the data.

Third, a number of sub-themes and sub-codes were identified. The established sub-codes were grouped under the main thematic codes, re-defined during the coding process, and applied to the remaining data.

Fourth, the inductive and deductive analytical interpretation of the data is presented.

The line-by-line coding process used mainly manual coding strategy and NVivo 12. The data analysis process revealed four main themes for students' integration in the host society: (1) Individual factors affect economic integration; (2) societal factors affect economic integration; (3) social integration; and (4) measures for improvement. These main themes were divided into sub-themes, as shown in Table 1.

Table 1. Analysis categorization system and coding.

\begin{tabular}{|c|c|c|}
\hline Main Themes & & Coding \\
\hline \multirow[t]{2}{*}{ Economic Integration } & Individual factors & $\begin{array}{l}\text { - Language issues } \\
\text { - Job-related skill and field } \\
\text { - Family reunion concern } \\
\text { - Communication skills }\end{array}$ \\
\hline & Societal factors & $\begin{array}{c}\text { - Unequal work opportunity } \\
\text { - Career development glass ceiling } \\
\text { - Uncompetitive salary/award system for high-skilled talent } \\
\bullet \quad \text { Foreigners fill in niche job market }\end{array}$ \\
\hline Social Integration & & $\begin{array}{l}\text { - Lack of deep contact } \\
\text { - Lack of professional network }\end{array}$ \\
\hline Measures for Improvement & $\begin{array}{l}\text { Individual } \\
\text { Structural }\end{array}$ & $\begin{array}{l}\text { • Mentality and attitude } \\
\text { - Entrepreneurial job-seeking approach } \\
\text { - Internationalization of Finnish work environment }\end{array}$ \\
\hline
\end{tabular}

In presenting the findings, no personal data is disclosed that may cause the interviewees to be recognized. The anonymity of respondents was protected by using only gender and university subject major to characterize the respondents. Citations from the interviews conducted in Mandarin Chinese were translated into English by the author. In addition, an internal expert who was familiar with the research offered comments on data analysis and translation process. 


\section{Findings}

\subsection{Economic Integration}

\subsubsection{Individual Factors}

Chinese students who studied in the Finnish universities have varied aspirations to stay in the host society after graduation. Some of them would like to remain in the host society for family reasons, others would prefer to stay in the host society due to their preference for the socio-cultural environment of the host society. Despite their varied reasons for wishing to stay, they shared a common understanding that the utmost important aspect of integration was finding suitable job opportunities and having networks with the local people, while finding employment was often mentioned as the top priority. However, the interviewees also shared the same feeling of frustration due to the difficulties of finding jobs in Finland. For instance, one of the interviewees said in her interview:

Interviewee: Of course, I want to become integrated into Finnish society, but it is not so easy! For people like me, finding a job is the first and uttermost problem. When you do not have a job, your social circle will be very small and limited. Basically, all you are interacting with are Chinese people. For instance, people like my neighbors who are neither studying nor working, then all their networks are Chinese. How do you integrate into Finnish society in such a case? Finnish people are not so open that they are easy to make friends to begin with [ ... ].

Interviewer: Why do you think it is so difficult to find jobs?

Lin: First, (it depends on) your field; second, language skills; third, I do not want to be so straightforward, for instance if you are as good as other Finnish candidates, who do you think they would recruit? Of course, they would recruit the Finnish candidate.

(Female, mathematics)

\section{(1) Language issues}

If Finland is to train and retain more global talent, it remains debatable whether international students aiming to stay on after graduation should invest more time to learn a skill that is highly valued in the labor market, or spend time to learn Finnish. Since Finland is a non-Anglophone country, the local language can pose a great challenge to Chinese students' integration both economically and socially. A number of studies have noted the importance of language skills for migrants' integration (e.g., [66,67]). According to earlier research, the conclusion always seems to be that international graduates who wish to stay in Finland cannot easily find suitable jobs due to their limited Finnish language skills (see for instance [47]). One of the interviewees said:

Finnish language is one of the main obstacles. Taking some Finnish language course can never qualify you to do what a Finnish native can do.

(Female, statistics)

Since most students came to study in Finland in English-taught programs, this research found that the majority of the students had not yet acquired fluent Finnish skills to enable them to work in Finnish before graduation. Among all the interviewees who participated in this research, only two people spoke relatively fluent Finnish and they were able to work in Finnish-both of them majored in Finnish studies during their bachelor's studies. However, contrary to the traditional view that Finnish is the major obstacle to their economic integration, some interviewees argued that being able to work in English was enough. For instance, one of the interviewees said:

If you ask 100 Chinese people who are working in highly skilled positions in Finland, I believe most of their working language would be in English. Maybe 60 to 70 percent of them 
use English at work. I can only say that if you know Finnish, it helps you to understand their ideas, local and corporate culture as well as society, which will be a plus, but it is not a decisive factor.

(Female, higher education)

Another interviewee also expressed similar ideas:

Interviewer: When you say they have good language skills; do you mean Finnish or English language skills?

Interviewee: When I say language, I mainly mean English. Because as a foreigner, when you are trying to find a job in Finland, I think most of the people will be mainly working in English. Whether your Finnish is good or not is not the decisive factor. Your English, even though not perfect, must be clear and lucid when you try to express yourself. You need to be able to use English to express in-depth thoughts. [ ... ] Because no matter how good your Finnish is, it will never be as good as Finns, right?

(Female, marketing)

(2) Job-related skill and field

Several interviewees expressed their opinion that being highly skilled in a field that is highly demanded in the Finnish labor market might be more important for job seeking than investing all the efforts to study Finnish. For instance, several interviewees mentioned that being highly competent in technical fields such as data analytics and programming often open doors for many job positions. In addition, one interviewee mentioned that there seems to be a lack of nurses and care workers in Finland. For instance, one interviewee from an IT background expressed the opinion that his job-related skills were far more important than his knowledge of the local language.

I think if you are good enough in your (major-related) skills, you can find a job anywhere. [ ... ] For us who study computer science, even if we are facing someone who does not speak English, we can still read each other's code, right? That is why even if I learn Finnish really well, if I am not good enough in my professional skill, I still cannot find any job.

(Male, computer science)

Clearly, this research shows that in a non-Anglophone country, both the local language, Finnish, and also English mediate the students' integration to different extents. Furthermore, the findings of this research challenge the traditional view that lack of Finnish skills is the major barrier that prevents students from becoming employed. Since the international graduates are competing in the highly skilled labor market, their skills may often be the most valuable asset to be competitive in the Finnish job market, while Finnish language skills may be an additional advantage.

As more and more Finnish companies and institutions are operating internationally, English is more and more accepted as a working language. Thus, it may be advisable for students to explore the local job market situation to see which sectors have higher demand for international workers so that they can set clear goals for their careers and strategies for their future employment.

\section{(3) Family reunion concerns}

Another difficulty for integration and long-term settlement in Finland mentioned by some of the interviewees was concern about family unification with their parents. Currently, the Finnish immigration policy only recognizes nuclear family, which consists of spouses and their children. However, many Chinese overseas students will face the challenge of taking care of their parents when they are older if they decide to settle down in Finland. Once of the interviewees said: 
If Finland hopes that more outstanding Chinese highly skilled workers will settle in Finland, how those people can take care of their parents if they decide to live here is a big issue. Because we are the single-child generation. According to the current migration policy in Finland, our parents cannot come to live here. They can only come every year for a maximum of three months. When we are still young, it is not a problem. But what are we supposed to do if we are older and our parents need to be taken care of extensively? Then we have to give up (living here) ultimately, right? Because Chinese parents and children are very close, and as a single child one cannot leave one's parents at home when they are old. I think that Finland should allow those with permanent residence permits and type A visas to bring their parents here without providing any social benefit. Thus, the children can be reunited with their parents and solve many issues.

(Male, artificial intelligence)

\section{(4) Communication skills}

In addition, some interviewees also mentioned that communication skills are also very important, since they would need to fluently, confidently, and logically 'sell' themselves to the employers. After the intercultural adaptation process in university, it is also very important for the students to be confident to express themselves in various multicultural settings, since the students are expected to work in multi-cultural work environments or international projects that they would need to act as a cross-cultural communication bridge. One interviewee said:

I think some students are not good at communicating or expressing themselves. They have a lot of ideas but do not know how to express logically with key points. Another issue is that many people are not confident with themselves. They always feel they are not good enough, or think that other people will discriminate against them. [... ] But those people who found jobs are basically very confident and self-assured.

(Female, MBA)

\subsubsection{Societal Factors}

\section{(1) Unequal work opportunities}

From the interviews it is clear that, besides individual factors, there are also societal factors that contribute to the students' difficulties with integration. Many interviewees said that they did not feel that they had the same opportunities and access to valuable resources (such as job opportunities) as the native Finns. Some positions might require job holders to speak fluent Finnish, which in some ways can be used to exclude foreigners. When asked about equality of job opportunity for foreigners, almost all the participants said that they did not think they had the same opportunities for finding jobs or promotion as native Finns, one of the interviewees said:

Interviewer: Do you think we have the same opportunities for finding jobs and for promotion like Finns?

Interviewee: For sure we don't have the same opportunities (for finding jobs and job promotion). You have to be much better than the Finns, and not just a little bit better. For the same job, if a Finn can do it, you need to be much better (in doing it), and bring much more value, this is obvious. (There is) inequality in finding job opportunities, and also seeking for promotion. Although theoretically, this is an equal society, but in reality, it is not equal. Finding job opportunities (for foreigners) is the biggest challenge.

(Male, signal processing)

Some interviewees aiming at an academic career expressed similar feelings of exclusion from opportunities in academia: 
For instance, when they try to recruit people, and if you are more or less at the same level as other, Finnish applicants, who do you think they would recruit? Of course, a native Finn. If your Finnish is not good enough so that you can use it fluently to teach, then of course they would consider Finns, because most of their students are still Finnish students. Of course, the native people will have more advantage. [ ... ] Unless you have something extra to bring than the Finns, right? Unless you are really good at doing research. Otherwise why would they hire you and set up English-taught courses (instead of Finnish-taught courses) due to the fact that you are hired here.

(Female, mathematics)

Since it only recently changed from a country of emigration to immigration, preference and trust for hiring from the native population is quite common. Finnish and EU legislation also clearly stipulate that the member states' employers should first consider hiring local people, then EU citizens, and finally non-EU citizens if they are not able to find people of satisfactory qualification in the local job market [68]. It is also due to linguistic and cultural concern, because although people can speak English, communication would still be easier and more efficient in Finnish. Thus, unless the work environment strongly demands internationalization, many jobs will prioritize the hire of Finnish people. For instance, one interviewee said:

I submitted a lot of applications, but I rarely got any interviews, only one in a year. I went to the university careers service and they said my resumé was impeccable. I think, to be honest, even for technical jobs, they would still prefer to hire natives to work in Finnish. Because if they speak the same language, the work efficiency will be much higher. That is why even if your resumé is so outstanding, your project experience is richer, and your grades are good, they would still not hire you, and finding a job depends purely on luck. If their team are not all Finnish, if they have one foreigner and they begin to work in English, then they wouldn't mind hiring another one.

(Male, computer science)

(2) Foreigners fill in niche job market

Several interviewees mentioned that highly skilled foreigners tend to fill the niche job market that native Finns either do not want to do, or are not skilled enough to do. Another interviewee also shared the same feeling of marginalization. It seems that from her point of view, some of the recruitment practices only favor Finnish applicants, and foreigners have less chance except by filling in a market niche that native people are not interested in. It seems that such recruitment practices can both result from a linguistic and cultural preference that the employers prefer to work in their native language and with people from similar cultural background. She said in the interview:

I don't think that I have the same opportunities for finding jobs/seeking promotion as the native Finns. It seems that we can only work in the fields where the native Finns are not interested to work. For example, statistical analysis seems to be one of my limited options. And this field attracts few, if any, Finnish educational researchers. I based my assumption on some real experiences. [ ... ] In one of the international projects that I got to know at its start, there was a vacant post-doc position which seemed to me very relevant to my husband. When I suggested his name to the project director, he said clearly that this position cannot be offered to a non-Finnish researcher.

(Female, education)

However, another interviewee expressed her understanding for such practice, since recruiting foreigners might impose unforeseeable costs and risks for the Finnish employers, including the added communication costs for using English instead of Finnish for internal communication. Lack of an 
existing multicultural working environment also makes employers hesitant towards hiring foreigners. She shared her opinion on the potential conditions under which Finnish employers would like to hire a foreign worker:

On many occasions, when they want to recruit a foreigner such as a Chinese student, there must be at least three reasons. First, either they want to get into the Chinese market and they need someone who understands the Chinese market and culture, right? Second, because this person can bring extra value (more than the Finns). Third, it's because they have such a policy that the project itself requires hiring people of international background. Otherwise, they wouldn't just hire a foreigner (over a local person).

(Male, MBA)

(3) Career development glass ceiling

In addition to unequal opportunities to find jobs due to employers' strong preference for native people, many interviewees also mentioned that they were concerned about their career development in Finland, since they already see the career development glass ceiling if they plan to remain in Finland. For many PhDs who are conducting research in Finland, the scarce chance for obtaining a permanent position is a huge disadvantage for their future career development. For instance, one interviewee said:

There are limitations for career development in Finland, since it is a small country with limited job opportunities. Many positions, you cannot make it unless you are a Finn. [ ... ] As you see, university professors are almost all Finns. Rarely any foreigner makes it to professor, no matter how good you are. Or even if you are a professor, you cannot make it to department head, dean, or university rector. The local societal structure already determined that those positions are only for Finns. And if you look at many Chinese's professions, they are obviously just low-level technical migrant workers, right? Rarely do they make it to the managerial level in Finnish companies. This is an invisible glass ceiling. For people with ambition, this is a huge set-back.

(Male, computer vision)

Another interviewee also expressed similar opinion:

For instance, one of the professors at the university once said to me that finding a tenure track position (after completing a doctorate) is likely to be exclusively reserved for Finns. Alternatively, he suggested selecting a post-doc position because for this option there are some organizations that can support non-Finnish applicants.

(Female, mechanical engineering)

In addition to career development glass ceiling, several doctoral student interviewees mentioned that there is lack of opportunity for them to develop their career during their studies. Since teaching skills are often required for finding jobs, their current host institutions do not open enough English-taught courses for them to teach. One interviewee said:

I tried many times to ask my faculty whether I could teach some courses, but I never got any opportunity to teach any course in the faculty. But the other Finnish doctoral researchers seemed to have no problem finding courses to teach.

(Female, medicine)

(4) Uncompetitive salary/award for high-skilled talent

Some interviewees also said the high tax system and high living cost resulted in lower salary for high-skilled talent in comparison to other regions in the world, such as North America and East Asia. Since Finland is a high welfare state, the tax imposed on salary is therefore relatively high compared to other countries. Meanwhile, some interviewees also said the reward system for highly skilled talent who have high research output is also limited. 


\subsection{Social Integration}

(1) Lack of deep contact

A lot of the interviewees recognized the importance of having Finnish friendship contacts and networks if they really wanted to stay and integrate into the local society. However, they also described the difficulties of establishing deeper friendships or contacts with local people. One of the interviewees said:

I think it's not so easy to become friends with Finns. Because not everyone is so open-minded that they would like to be friends with you. Sometimes they would only say hi if you meet in the neighborhood or something. Even if you have a job here, like (someone's name), but how many of your Finnish colleagues can become friends to have further contact after work, right? I think, first of all, there is a cultural difference. Second, you might need to have something in common with them, like a common hobby. And especially for us it is quite difficult to find a job. So, if you don't have a job, your social network is quite narrow.

(Female, sociology)

(2) Lack of professional network

Despite the difficulties, the participants emphasized the importance of forming networks with local people as they open doors for the interviewees to understand local culture, establish contacts, and potentially find job opportunities in the host society:

I often receive a lot of invitations to networking events. I know that a lot of Chinese are not interested in joining those networking events. They feel uncomfortable about it. In fact, from participating in those events, I got a lot of useful networks. Those are things that help you to sow the seeds for your future in this society.

(Male, media studies)

This study also confirms that having a local social network will help students alleviate their loneliness and homesickness as suggested by earlier research [59]. Having someone who could recommend them for certain job positions sometimes is much more useful than submitting their job applications online. One of the interviewees said that she managed to find a job due to a recommendation from her Finnish work mentor, who put her in touch with another employer through the mentor's personal network. One of the interviewees stressed the importance of reaching out proactively to the local society. She said:

If you decided to stay in Finland, then you must proactively integrate into Finnish society. Finnish people are like 'Jing Fen' ("jingfen", or "spiritually Finnish," a term that became popular on the Chinese internet, which is inspired by a comic from Finland called "Finnish Nightmares," describing the kind of people who prefer minimal social contact and avoid social situations), right? They will not actively seek to establish contact with you, if you don't try to communicate with them, you will never integrate. For me, there are two ways to integrate: The first is to study this country's language and culture. I started learning Finnish myself and to subscribe to the local Helsinki newspaper. In the beginning, I was reading an English version of that Helsinki paper. It gave me a lot of help to understand what was happening in Finnish society. I have continuously subscribed to this newspaper for around two years. It helps me to learn the language and to study Finnish culture. The second is that I try to establish networks with the local society. For a foreigner, there are so many difficulties to overcome, like finding jobs, going to see doctors, giving birth to children. If you do not ask other people to help, nobody will help you. [ ... ] Previously, I was working part-time for my employer, and established good networks and gained their trust. That is how I got the job that I am doing now.

(Female, education) 


\subsection{Potential Measures for Improvement}

(1) Mentality and attitude

One interviewee mentioned having a proactive attitude, self-confidence, and other valuable qualities that the individuals can adopt can help to improve their chances of being employed:

Those who can find jobs, first they must be brave enough (not afraid to lose face) to some extent, and second, have good language skills, be confident and honest. Or they have some good friends to recommend them, or they have done a lot of voluntary jobs without payment.

(Male, law)

\section{(2) Entrepreneurial job-seeking approach}

Although faced with many uncertainties and difficulties in finding jobs and potential discrimination in the Finnish labor market, one of the interviewees still said that she thought an individual's effort and determination to create a position for themselves is quite important for their own integration in Finland. She provided a potential strategy for those who are struggling to integrate, especially into the labor market:

I think when you met difficulties in (finding jobs), first, you must not avoid the problem. Second, you should not just complain every day about the social injustice or unequal opportunities for foreigners. You should just face the situation and find solutions. Don't overlook the power of habit. [...] I have another idea (for those who want to stay here): Even if some companies they do not have a specific position to open the market in China, and do not want to be international, I think you should have an entrepreneurial spirit to create positions for yourself. You can give them some ideas and lead them to think that they need to develop in Japan or Korea or China. When they see the potential value of your capability (to open up the Chinese market), maybe they will be able to provide a position for you to try. [ ... ] I think when there is no suitable position, you need to create the position yourself. [ ... ] I think that a strong will and determination are very important.

(Female, higher education)

(3) Internationalization of Finnish work environment

Some interviewees also mentioned that if Finnish society is to retain more global talent, it is not enough that they try to teach Finnish to newcomers. For highly skilled workers, they might also be highly mobile that they can also find work in other places around the world. Finnish society and working environment should also change to become more multicultural and use English so that they can make the newcomers feel at home. He said in the interview:

I think Finland needs to cultivate a more multicultural environment for highly skilled migrants and all the people. It is not enough that they only just provide Finnish courses for foreigners. I think a multi-cultural environment is seriously lacking in Finland. A lot of things and information are too oriented or focused on serving Finnish people, because a lot of information is only available in Finnish. But, they realized that if this country is to develop itself, it cannot only rely on Finnish, it needs new blood to enter into its system. Then how do you make those newly arrived people feel at home? I think they should convert more content into English and use English more often in meetings for the international employees.

(Male, electric engineering) 


\section{Conclusions}

This article demonstrates that as more and more countries are transitioning to a knowledge-based society and environmentally sustainable economy, attracting and retaining international students as global talent for boosting innovation rank high on the national agenda. International graduates have the linguistic and socio-cultural competences from both host and home countries, and are potentially an important link in building and sustaining a transnational innovation ecosystem. However, the paradox persists when it comes to practice at the local and institutional level. As the case study based on Chinese students' economic and social integration clearly illustrates, Chinese students face a number of challenges in their economic and social integration if they plan to remain in the local Finnish society after graduation. First, from an individual perspective, Finnish as the local language poses a significant challenge to their integration since most students came to study on English-taught programs and thus did not acquire fluent Finnish before graduation, while many employers would prefer to hire workers capable of working in Finnish. Lacking professional networks, which potentially result from lack of social integration with the local people, also led to difficulties in finding jobs among the interviewees. As the one-child generation, they also faced the concerns of a restrictive immigration policy preventing them from bringing their aged parents to take care of if they decided to settle down in the host society. Second, from a societal perspective, Finnish society and also employers are yet to become more open and multicultural to incorporate more foreigners into the Finnish working environment. Most of the interviewees reported not having the same access as native Finns to job opportunities or promotion. Such structural exclusion and marginalization of foreign highly educated workers may detract from such workers' desire to remain in the host society, and jeopardize the national strategy of retaining global talent.

This research identified three implications for students and other stakeholders: First, given the discussion on the language issue above, is it better for students to invest time and effort in acquiring skills highly valued in the labor market or in learning the local language? There seems to be no definite answer to this question, since the labor market demand is contextual and varies from one field to another. However, the interviews in this research suggest that, as highly skilled migrants, the students' job-related skills may be their most important asset with which to compete in the local job market. However, having local language skills besides their mother tongue and being fluent in English will undoubtedly be an advantage in their job seeking processes.

Second, while the students encountered numerous challenges during their integration processes, the current study suggests that the students may need to be more proactive and innovative in their economic integration strategies. This finding is consonant with the research by Cai (2014), which suggests that Chinese students can adopt an entrepreneurial job-seeking approach, that a job-seeker make proposals to potential employers by identifying their needs and utilizing their own special skills and talents to create a position for themselves. Besides possessing the hard skills, the students' soft skills, such as being confident, honest, and cooperative team players, can also play an important role in enhancing their economic integration.

Third, given the various societal barriers faced by Chinese students during their integration, should HEIs and local employers become more multi-cultural to accommodate and retain the global talent? As the present study suggests, integration should be a bi-directional process entailing migrant and host societies' mutual adaptation, both as individuals and as groups. The present findings suggest that Chinese students still face a certain degree of exclusion, not only from potential academic opportunities in the host HEIs, but also from the labor market and society more generally. As Finnish society is becoming increasingly aware of the importance of training and retaining international students as global talent, it can be argued that demanding that only the newcomers 'integrate' is not enough. The host environment (nation-states and organizations) also need to be more open and multiculturally oriented to enhance these highly skilled individuals' capacities to integrate and innovate. By creating an institutional or societal environment that is open to hiring and promoting people from diverse 
ethnic and cultural backgrounds to work together, global talent (such as the Chinese students) will be encouraged to utilize their transnational capital and innovative capacity to make a greater contribution.

The findings of this study also suggest that Chinese students' economic and social integration are mutually supportive. Those Chinese students willing to reach out from their comfort zone to meet more local people and obtain more professional opportunities may also have better chances of finding job opportunities in the host society after graduation. It is also clear that those students with work experience in the local society also have opportunities to expand their social networks with the host natives. Overall, international students' economic and social integration is not only a crucial step in their entry into the local society, but also an attractive opportunity for hosting organizations and employers to build multicultural environments that can potentially enhance their productivity and build future sustainable development.

The present research will hopefully be useful for understanding the economic and social integration of Chinese students overseas, especially in the contexts of non-Anglophone countries. Despite its significance, it focuses only on Chinese students in the interviews conducted for this research. To further understand how to better retain international graduates, more studies on Chinese and other groups of international students in similar societal contexts should be conducted to corroborate the present findings. Further research is also needed to include the voices of employers, managerial staff of HEIs, and policymakers in order to assess their understanding and strategies for retaining highly qualified graduates. Finally, since the broad concept of integration for international students has the potential to include academic integration and cultural integration (cross-cultural learning), given the findings presented here, it would be useful to apply quantitative or mixed methods research to ascertain the extent to which these factors are primarily connected with students' integration.

Funding: This research received funding from the University of Manchester open-access publication funding.

Acknowledgments: The author is grateful for Yuzhuo Cai's comments on an earlier version and the two anonymous reviewers for their valuable comments.

Conflicts of Interest: The author declares no conflict of interest.

\section{References}

1. Rilla, N.; Deschryvere, M.; Oksanen, J.; Raunio, M.; van der Have, R. Immigrants in the Innovation Economy-Lessons from Austria, Canada, Denmark and The Netherlands; 9522875031; Finnish Prime Minister's Office: Helsinki, Filand, 2018.

2. Suutari, V.; Wurtz, O.; Tornikoski, C. How to Attract and Retain Global Careerists: Evidence from Finland. In Global Talent Management: Challenges, Strategies, and Opportunities; Al Ariss, A., Ed.; Springer International Publishing: Berlin/Heidelberg, Germany, 2014; pp. 237-249. [CrossRef]

3. Michaels, E.; Handfield-Jones, H.; Axelrod, B. The War for Talent; Harvard Business Press: Boston, MA, USA, 2001.

4. Cai, Y.; Ramis Ferrer, B.; Luis Martinez Lastra, J. Building University-Industry Co-Innovation Networks in Transnational Innovation Ecosystems: Towards a Transdisciplinary Approach of Integrating Social Sciences and Artificial Intelligence. Sustainability 2019, 11, 4633. [CrossRef]

5. Aydemir, A.B. Skill-based immigration, economic integration, and economic performance. IZA World of Labor 2014. [CrossRef]

6. Li, Z.; Lowe, J. Mobile student to mobile worker: The role of universities in the 'war for talent'. Br. J. Sociol. Educ. 2016, 37, 11-29. [CrossRef]

7. Kuptsch, C. Students and talent flow-the case of Europe: From castle to harbour. In Competing for Global Talent; Kuptsch, C., Eng Fong, P., Eds.; International Institute for Labour Studies: Geneva, Switzerland, 2006; pp. 33-61.

8. Findlay, A.M. Brain Strain and Other Social Challenges Arising from the UK's Policy of Attracting Global Talent. In Competing for Global Talent; Kuptsch, C., Eng Fong, P., Eds.; International Institute for Labour Studies: Geneva, Switzerland, 2006; pp. 65-86. 
9. Raunio, M.; Forsander, A. The Welfare State in Competition for Global Talent: From National Protectionism to Regional Connectivity-the Case of Finland; Peter Lang: Frankfurt am Main, France, 2009.

10. Scullion, H.; Collings, D.G.; Caligiuri, P. Global talent management. J. World Bus. 2010, 45, 105-108. [CrossRef]

11. Mok, K.H.; Chan, S.-J. Editorial: Promoting global cities status: Talent attraction and retention in Asia. Glob. Soc. Educ. 2020, 18, 1-6. [CrossRef]

12. Chaminade, C.; Nielsen, H. Transnational Innovation Systems; Eclac: Santiago de chile, Chile, 2011.

13. Sotarauta, M.; Heinonen, T.; Sorvisto, P.; Kolehmainen, J. Innovation ecosystems, competencies and leadership: Human spare parts and venture finance ecosystems under scrutiny. Tekes Rev. 2016, 329, 2016.

14. Oh, D.-S.; Phillips, F.; Park, S.; Lee, E. Innovation ecosystems: A critical examination. Technovation 2016, 54, 1-6. [CrossRef]

15. Walrave, B.; Talmar, M.; Podoynitsyna, K.S.; Romme, A.G.L.; Verbong, G.P. A multi-level perspective on innovation ecosystems for path-breaking innovation. Technol. Forecast. Soc. Chang. 2018, 136, 103-113. [CrossRef]

16. Leung, M.W.H. Unraveling the Skilled Mobility for Sustainable Development Mantra: An Analysis of China-EU Academic Mobility. Sustainability 2013, 5, 2644-2663. [CrossRef]

17. Galán-Pérez, A.; Grumazescu, I.; Gunthorpe, K.; Limburg, A.; Roche, N.; Sciacchitano, E.; van Leeuwen, J.; Almevik, G. Fostering cooperation in the European Union on skills, training and knowledge transfer in cultural heritage professions. In Proceedings of the Professionalism in the Built Heritage Sector: Edited Contributions to the International Conference on Professionalism in the Built Heritage Sector, Arenberg Castle, Leuven, Belgium, 5-8 February 2018; p. 61.

18. G.H.K.Consulting; Renming University. EU-China Student and Academic Staff Mobility: Present Situation and Future Developments. 2011. Available online: https:/ec.europa.eu/assets/eac/education/internationalcooperation/documents/china/mobility_en.pdf (accessed on 4 May 2020).

19. Shumilova, Y.; Cai, Y. Three Approaches to Competing for Global Talent: Role of Higher Education. In Global Perspectives and Local Challenges Surrounding International Student Mobility; Krishna, B., Charlotte, F., Eds.; IGI Global: Hershey, PA, USA, 2016; pp. 114-135. [CrossRef]

20. Teichler, U. The Changing Debate on Internationalisation of Higher Education. High. Educ. 2004, 48, 5-26. [CrossRef]

21. Maahanmuuttovirasto Migrationsverket Finnish Immigration Service. Residence Permit Application for Extended Permit to Look for Work or to Start a Business. Available online: https://migri.fi/en/extendedpermit-to-look-for-work (accessed on 2 February 2020).

22. Findlay, A.; Packwood, H.; McCollum, D.; Nightingale, G.; Tindal, S. Fees, flows and imaginaries: Exploring the destination choices arising from intra-national student mobility. Glob. Soc. Educ. 2018, 16, 162-175. [CrossRef]

23. Huang, R.; Turner, R. International experience, universities support and graduate employability-perceptions of Chinese international students studying in UK universities. J. Educ. Work 2018, 31, 175-189. [CrossRef]

24. Spencer-Oatey, H. Transformative learning for social integration: Overcoming the challenge of greetings. Intercult. Educ. 2018, 29, 301-315. [CrossRef]

25. Cheng, M.; Adekola, O.A.; Shah, M.; Valyrakis, M. Exploring Chinese students' experience of curriculum internationalisation: A comparative study of Scotland and Australia. Stud. High. Educ. 2018, 43, 754-768. [CrossRef]

26. Li, H.; Pitkänen, P. Understanding the Integration of Mainland Chinese Students: The case of Finland. Nordic J. Mir. Res. 2018, 8, 107-115. [CrossRef]

27. Spencer-Oatey, H.; Dauber, D. Internationalisation and student diversity: How far are the opportunity benefits being perceived and exploited? High. Educ. 2019, 78, 1035-1058. [CrossRef]

28. Li, H. Academic Integration of Chinese Students in Finland and Germany: A Comparative Perspective. Front. Educ. China 2019, 14, 234-256. [CrossRef]

29. Yu, B.; Wright, E. Socio-cultural adaptation, academic adaptation and satisfaction of international higher degree research students in Australia. Tert. Educ. Manag. 2016, 22, 49-64. [CrossRef]

30. Jean-Francois, E. Exploring the perceptions of campus climate and integration strategies used by international students in a US university campus. Stud. High. Educ. 2019, 44, 1069-1085. [CrossRef]

31. IOM. IOM and Migrant Integration; Labour Migration and Human Development Division International Organization for Migration (IOM): Geneva, Switzerland, 2018. 
32. Li, H. Aspiration and Integration infrastructure: A study on Chinese students' integration in Finland and Germany. Working Paper-Centern on Migration, Citizenship and Development. 2018, 160, pp. 1-32. Available online: https://nbn-resolving.org/urn:nbn:de:0168-ssoar-58135-2 (accessed on 5 May 2020).

33. Tholen, G. What can research into graduate employability tell us about agency and structure? Br. J. Sociol. Educ. 2015, 36, 766-784. [CrossRef]

34. Brooks, R.; Everett, G. The predominance of work-based training in young graduates' learning. J. Educ. Work 2008, 21, 61-73. [CrossRef]

35. Smetherham, C. The labour market perceptions of high achieving UK university graduates: The role of the first class credential. High. Educ. Policy 2006, 19, 463-477. [CrossRef]

36. Entzinger, H.; Biezeveld, R. Benchmarking in Immigrant Integration; No. DG JAI-A-2/2002/006; European Commission: Brussel, Belgium, 2003.

37. Kindler, M.; Szulecka, M. The economic integration of Ukrainian and Vietnamese migrant women in the polish labour market. J. Ethn. Migr. Stud. 2013, 39, 649-671. [CrossRef]

38. Fugate, M.; Kinicki, A.J.; Ashforth, B.E. Employability: A psycho-social construct, its dimensions, and applications. J. Vocat. Behav. 2004, 65, 14-38. [CrossRef]

39. Lunn, J. Global perspectives in higher education: Taking the agenda forward in the United Kingdom. J. Stud. Int. Educ. 2008, 12, 231-254. [CrossRef]

40. Brooks, R.; Fuller, A.; Waters, J.L. Changing Spaces of Education: New Perspectives on the Nature of Learning; Routledge: Abingdon-on-Thames, UK, 2012.

41. Shumilova, Y.; Cai, Y. Factors affecting the employability of international graduates. Int. Sci. J. Univ. Leadersh. 2015, 1, 24-30.

42. Sherry, M.; Thomas, P.; Chui, W.H. International students: A vulnerable student population. High. Educ. 2010, 60, 33-46. [CrossRef]

43. Gribble, C.; Rahimi, M.; Blackmore, J. International students and post-study employment: The impact of university and host community engagement on the employment outcomes of international students in Australia. In International Student Connectedness and Identity; Springer: Berlin/Heidelberg, Germany, 2017; pp. 15-39.

44. George, U.; Chaze, F. Discrimination at work: Comparing the experiences of foreign-trained and locally-trained engineers in Canada. Can. Ethn. Stud. 2014, 46, 1-21. [CrossRef]

45. Kaas, L.; Manger, C. Ethnic discrimination in Germany's labour market: A field experiment. Ger. Econ. Rev. 2012, 13, 1-20. [CrossRef]

46. Mauldin, R.L.; Greenfield, J.C.; Kusmaul, N.; Fields, N.L.; Wladkowski, S.P.; Gibson, A. Using Social Network Analysis to Assess Professional Network Development among AGE SW Pre-Dissertation Fellowship Program Participants. J. Gerontol. Soc. Work 2019, 62, 873-888. [CrossRef]

47. Shumilova, Y.; Cai, Y.; Pekkola, E. Employability of International Graduates Educated in Finnish Higher Education Institutions; VALOA-project, Career Services; University of Helsinki: Helsinki, Finland, 2012.

48. Cai, Y. International graduates from Finland: Do they satisfy the needs of Finnish employers abroad? J. Res. Int. Educ. 2012, 11, 19-31. [CrossRef]

49. McQuaid, R.W.; Lindsay, C. The concept of employability. Urban Stud. 2005, 42, 197-219. [CrossRef]

50. Clarke, M. Rethinking graduate employability: The role of capital, individual attributes and context. Stud. High. Educ. 2018, 43, 1923-1937. [CrossRef]

51. Tymon, A. The student perspective on employability. Stud. High. Educ. 2013, 38, 841-856. [CrossRef]

52. Chaloff, J. The Impact of EU Directives on the labour migration framework in EU countries. OECD Social, Employment and Migration Working Papers. 2016, p. 180. Available online: https://doi.org/10.1787/ 5jlwxbzpwh33-en (accessed on 5 May 2020). [CrossRef]

53. Liebkind, K.; Larja, L.; Brylka, A. Ethnic and gender discrimination in recruitment: Experimental evidence from Finland. 2016. Available online: https://www.psycharchives.org/handle/20.500.12034/1392 (accessed on 5 May 2020).

54. Ware, N.C.; Hopper, K.; Tugenberg, T.; Dickey, B.; Fisher, D. A theory of social integration as quality of life. Psychiatr. Serv. 2008, 59, 27-33. [CrossRef] [PubMed]

55. Mei, W.; Parkay, F.W.; Pitre, P.E. Student-Faculty Interaction: A Key to Academic Integration and Success for Ethnic Minority Students at a Major University in Southwest China. Front. Educ. China 2016, 11, 483-502. [CrossRef] 
56. Schartner, A. 'You cannot talk with all of the strangers in a pub': A longitudinal case study of international postgraduate students' social ties at a British university. High. Educ. 2015, 69, 225-241. [CrossRef]

57. Sawir, E.; Marginson, S.; Deumert, A.; Nyland, C.; Ramia, G. Loneliness and international students: An Australian study. J. Stud. Int. Educ. 2008, 12, 148-180. [CrossRef]

58. Bochner, S.; McLeod, B.M.; Lin, A. Friendship patterns of overseas students: A functional model. Int. J. Psychol. 1977, 12, 277-294. [CrossRef]

59. Smith, R.A.; Khawaja, N.G. A review of the acculturation experiences of international students. Int. J. Intercult. Relat. 2011, 35, 699-713. [CrossRef]

60. Rienties, B.; Luchoomun, D.; Tempelaar, D. Academic and social integration of Master students: A cross-institutional comparison between Dutch and international students. Innov. Educ. Teach. Int. 2014, 51, 130-141. [CrossRef]

61. Kim, Y.Y. Becoming Intercultural: An Integrative Theory of Communication and Cross-Cultural Adaptation; Sage: Thousand Oaks, CA, USA, 2001.

62. Kvale, S.; Brinkmann, S. InterViews: Learning the Craft of Qualitative Research Interviewing, 3rd ed.; Sage Publications: Thousands Oaks, CA, USA, 2015.

63. Silverman, D. Interpreting Qualitative Data: Methods for Analyzing Talk, Text and Interaction; Sage: Thousand Oaks, CA, USA, 2006.

64. Welch, C.; Piekkari, R. Crossing language boundaries: Qualitative interviewing in international business. Manag. Int. Rev. 2006, 46, 417-437. [CrossRef]

65. Boyatzis, R.E. Transforming Qualitative Information: Thematic Analysis and Code Development; Sage: Thousand Oaks, CA, USA, 1998.

66. Van Riemsdijk, M.; Basford, S.; Burnham, A. Socio-cultural incorporation of skilled migrants at work: Employer and migrant perspectives. Int. Migr. 2016, 54, 20-34. [CrossRef]

67. Phillimore, J.; Humphris, R.; Khan, K. Reciprocity for new migrant integration: Resource conservation, investment and exchange. J. Ethn. Migr. Stud. 2018, 44, 215-232. [CrossRef]

68. Shutes, I. Work-related conditionality and the access to social benefits of national citizens, EU and non-EU citizens. J. Soc. Policy 2016, 45, 691-707. [CrossRef]

(C) 2020 by the author. Licensee MDPI, Basel, Switzerland. This article is an open access article distributed under the terms and conditions of the Creative Commons Attribution (CC BY) license (http://creativecommons.org/licenses/by/4.0/). 